\title{
STUDY OF USAGE PATTERNS AND EFFECTS OF SMART PHONE AMONG THE MEDICAL STUDENTS OF NIZAMABAD, TELANGANA
}

\author{
T. Dinesh Kumar' ${ }^{1}$ P. Anupama²
}

${ }_{1}^{1}$ Assistant Professor, Department of Community Medicine, GMC, Nizamabad, Telangana, India.

${ }^{2}$ Assistant Professor, Department of Community Medicine, GMC, Secunderabad, Telangana, India.

\begin{abstract}
BACKGROUND
ABSTRACT

Smartphone has greatly impacted education, health and social life. It has drastically changed the cultural norms and behaviour of individuals. ${ }^{1}$ This study focuses on the usage patterns, accompanying behaviour and effects of smartphones among medical students. ${ }^{2}$ They make it easy to stay in touch with people but their excessive use has raised concern, which might have negative impact on health and studies. Some of the hazards related to the smartphone use include headache, sleep disturbance, lack of concentration and impairment of short-term memory. ${ }^{3}$
\end{abstract}

\section{METHODS}

This cross-sectional study was conducted among the medical undergraduate students of Govt. Medical College, Nizamabad, Telangana State, during the period of October-December 2014 4,5,6. A convenient sample of 300 medical students was considered for this study. Participants were selected through simple random sampling and a pre-designed, semi-structured questionnaire was given to each student. 300 medical students were given pre-tested, pre-designed, semi-structured \& self-administered questionnaire and the data regarding the usage patterns and effects of smart phone among the medical students of Nizamabad was collected.

\section{RESULTS}

Among the study subjects, the following results were obtained from our study, after analysis of data.

- $\quad 39.3 \%$ of them were using smartphone for more than 2 years.

- $\quad 96.7 \%$ of them feel that their knowledge improved.

- $22.6 \%$ of them were using smart phones for more than $6 \mathrm{hrs} /$ day.

- $\quad 49.6 \%$ use them even after 11 P.M.

- Social networking was the most used feature.

- $72.3 \%$ use them in classrooms.

\section{CONCLUSIONS}

The pattern of use differs between males and females. Usage for social networking is more among females. Usage after midnight and chatting with strangers is more prevalent among males. Behaviours like getting annoyed/restless when interrupted, are a point of concern. Factors like using the smartphone till late in the night might cause less sleep which might lead to less concentration in the classrooms. Also, the usage while in classroom is very high, this might also affect their concentration on studies. Symptoms like headache, eyestrain and stress were found in majority of the students after using the smartphone for a long time. All these factors might affect their concentration, academic performance and also their health in the long run. ${ }^{3}$ In the existing scenario the need of the hour is to educate and create awareness among the students about the ill effects of over usage of smart phone, not only on their health but also on their studies and life style.

\section{KEY WORDS}

Smartphone, Medical Students, Effects of Smartphone, Social Networking

HOW TO CITE THIS ARTICLE: Kumar TD, Anupama P. Study of usage patterns and effects of smart phone among the medical students of Nizamabad, Telangana. J. Evolution Med. Dent. Sci. 2019;8(26):2081-2085, DOI: 10.14260/jemds/2019/458

\section{BACKGROUND}

Nowadays, smart phones are a major part of our life due to their usefulness. It is difficult to avoid such new technologies, while we all know the effect it has on the society and also on the environment.

'Financial or Other Competing Interest': None.

Submission 22-10-2018, Peer Review 12-06-2019,

Acceptance 19-06-2019, Published 01-07-2019.

Corresponding Author:

Dr. P. Anupama,

Assistant Professor,

Department of Community Medicine,

Gandhi Medical College,

Secunderabad, Telangana, India.

E-mail:drpanu16@gmail.com

DOI: $10.14260 /$ jemds $/ 2019 / 458$
Nevertheless, use of smartphones has exploded and they have become an essential part of business, commerce and society ${ }^{3}$. They make it easy to stay in touch with people, but their excessive use has raised concern, which might have negative impacts on health and studies. Some of the hazards related to the smartphone use include headache, sleep disturbance, lack of concentration and impairment of short term memory3 ${ }^{3}$ It has been shown that young people who use cell phones excessively have increased restlessness, more careless lifestyles and greater susceptibility to stress. $3,7,8$ Medical college students might be more vulnerable because of their heavy use of smartphones for study and work. Therefore, this study aimed to assess the usage patterns and the extent of influence of Smart phones on the Medical students who participated in this study. 


\section{Aim}

To study the usage patterns and effects of smart phone among the medical students of Nizamabad, Telangana.

\section{Objectives}

1. Frequency, Patterns- Time spent by medical students on smart phones.

2. Effects of smart phones usage on-

- Study disturbances.

- Social behaviour.

- Education performance.

\section{METHODS}

A descriptive cross-sectional study was conducted among the Medical undergraduate students of Govt. Medical College, Nizamabad, Telangana State, during the period of OctoberDecember 2014. A convenient sample of 300 medical students were considered for this study ${ }^{6}$. Participants were selected through Simple Random Sampling technique of 300 in number and a pre-designed, semi-structured questionnaire was self-administered to each student. All students who were willing to participate were included in the study. Data was entered and analysed with MS Excel and SPSS.

\section{Study Sample}

300 Medical Students were given pre-tested, Pre-designed, semi-structured \& self-administered questionnaire and the data collected regarding the usage patterns and effects of smart phone among the medical students of Nizamabad.

\section{Study Site}

Medical undergraduate students of Govt. Medical College, Nizamabad, Telangana.

\section{Study Design}

A cross-sectional survey, Participants were selected through simple random sampling and a pre-designed, semi structured questionnaire was self-administered to each student.

\section{Study Period}

October 2014 - December 2014.

\section{Inclusion Criteria}

Govt. Medical College, Nizamabad students who were willing to participate were included in the study.

\section{Exclusion Criteria}

Students not willing to participate in the study.

\section{Methodology}

A Pre-tested, Pre-designed \& semi-structured questionnaire was self-administered to, Participants willing to participate in the study. Data collected from the filled in questionnaire of the participants.

\section{Statistical Analysis}

Chi-square test was done and the association between social networking and the following factors was found to be statistically significant-
- Frequency of checking the phone.

- Usage even while in classroom.

- Preference to be with the smartphone even while at home.

- Getting restless/annoyed when interrupted.

- Feeling insecure when others used phone.

- Feeling sleepy very often in the classroom.

Also, the following associations for males vs females were found to be statistically significant. Data was entered with MS Excel 2007 and analysed using SPSS Ver.22.

\section{RESULTS}

The study population included 300 medical under graduates. The mean age of the study population was $21.3 \pm 1.2$ years. There were $39.7 \%$ males and $60.3 \%$ females $^{9}$. Around $8 \%$ of the subjects had no siblings and $65 \%$ of them had only one sibling. The per capita income was ranging from 2000 to 50,000 per month. Around $11.3 \%$ had per capita income more than 30,000 and $20.7 \%$ had more than 20,000 .

Around $39.3 \%$ of them were using smartphone for more than 2 years. Around $22.6 \%$ of them were using for more than 6 hrs/day. Almost 49.6\% use it beyond 11 P.M. in the night. 5 Gaming was the most used feature among $63 \%$ of males and $37 \%$ of females. Social networking was the most used feature among 79\% females and $21 \%$ males. ${ }^{10}$ Around $2 \%$ use for music and $1.7 \%$ use it for porn.

Almost $96.7 \%$ of them feel that the smartphone has helped them to gain knowledge. Around $72.3 \%$ use their smartphone even while in the classroom and 34\% feel sleepy in the classroom, very often. ${ }^{10}$ Around $31.7 \%$ feel that their grades have come down since they used the smartphone.11 Around $41 \%$ of them check their phone every 10-15 minutes. Around $30.7 \%$ prefer to be with their smartphone even while at home.

Around $59.7 \%$ of the students' parents complain that they are spending too much of their time with the smartphone.12,13 On being interrupted while they are on their smartphone, $44 \%$ feel restless to get back to their phone and $16 \%$ get annoyed with their family and ask them to leave. ${ }^{11,14,9}$ Almost $53.3 \%$ feel insecure when others use their smartphone. Around $46.7 \%$ of them carry their smartphone to the dining table and $20.3 \%$ complete their food in a hurry so as to attend to their smartphone. Around $26.7 \%$ carry their smartphone to the washroom.

Around $14 \%$ of them are not involved in any kind of outdoor activities. Around $16.3 \%$ of them feel that they have gained weight since they have been using smartphone ${ }^{15}$ Around $18.7 \%$ feel comfortable chatting even with strangers. Around $14 \%$ of them are not involved in any kind of outdoor activities. Around $16.3 \%$ of them feel that they have gained weight since they have been using smartphone. Almost $90 \%$ of them were aware of the radiation hazards of the smartphone. ${ }^{16,17}$

Almost $65 \%$ of them experienced headache, eyestrain and stress after using the smartphone for a long time. ${ }^{18}$ Overall $47.3 \%$ of the study subjects feel there is no better alternative to a smart phone. 

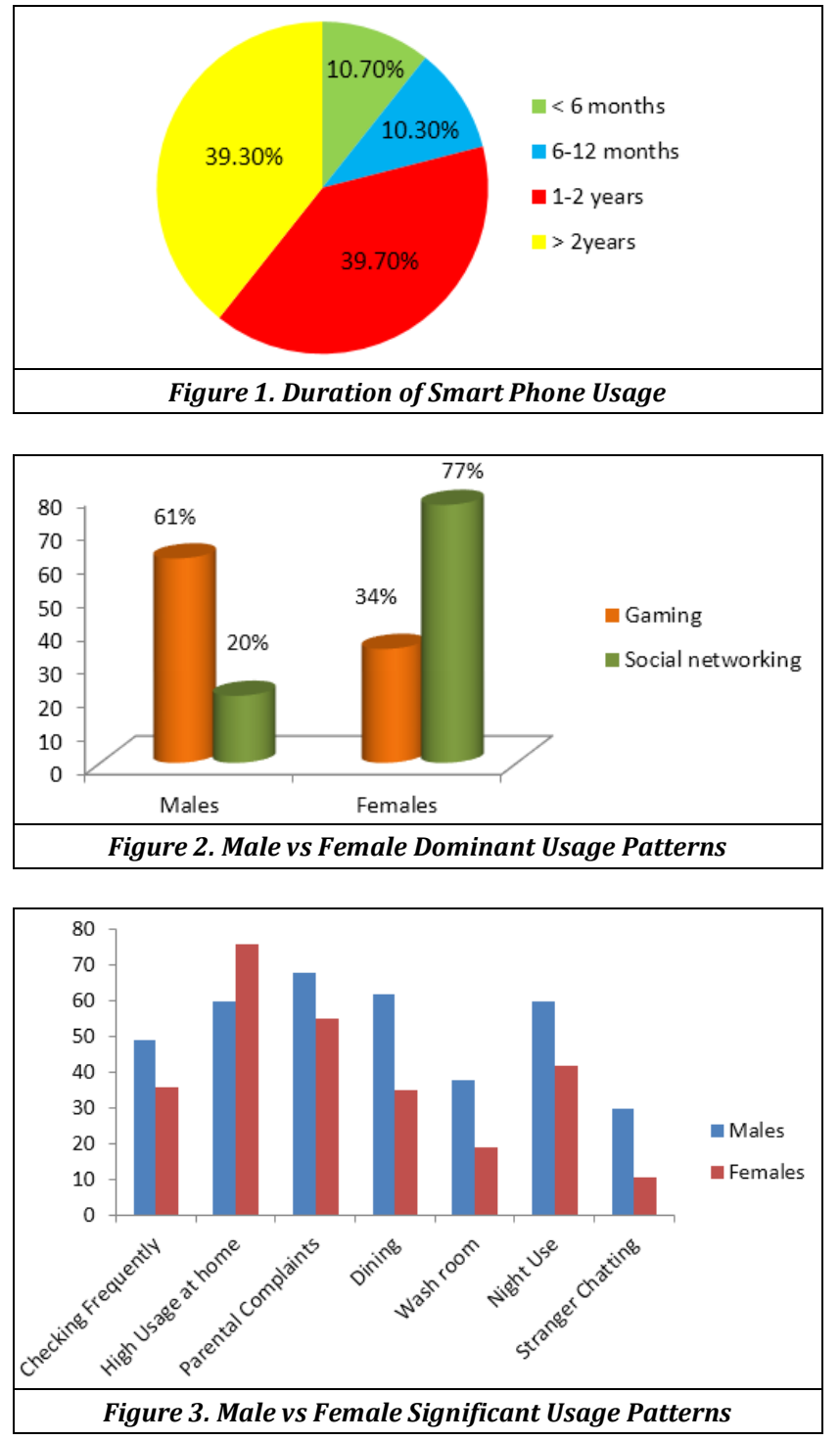

\begin{tabular}{|c|c|}
\hline Usage Patterns of Smart Phone & Percentage ( \% ) \\
\hline Using for > 8 hrs/ day & 10 \\
\hline Using while in Class room & 72 \\
\hline Checking the phone every 10-15 mins & 41 \\
\hline Maximum usage at home & 30.5 \\
\hline Parents complaining about over usage & 60 \\
\hline Using while Dining & 47 \\
\hline Using while in Wash room & 28 \\
\hline Sleeping with Smart Phone underneath Pillow & 58 \\
\hline Usage beyond 11 P.M. & 49.5 \\
\hline Table 1. Usage Patterns of Smart Phone \\
\hline
\end{tabular}

\begin{tabular}{|c|c|}
\hline Effects of Smart Phone Usage & Percentage ( \%) \\
\hline Head ache & 65 \\
\hline Weight gain & 17 \\
\hline No outdoor activity & 14 \\
\hline Eating in hurry & 20 \\
\hline Insecure when others use their Phone & 53 \\
\hline Annoyed on being Interrupted & 60 \\
\hline Feeling sleepy in Class room & 35 \\
\hline Grades dipped & 33 \\
\hline Table 2. Effects of Smart Phone Usage \\
\hline
\end{tabular}

\begin{tabular}{|c|c|}
\hline Attitude & Percentage (\%) \\
\hline Gained Knowledge & 98 \\
\hline Best time killer & 76 \\
\hline No better alternative & 48 \\
\hline Table 3. Attitude Towards Smart Phone Usage \\
\hline
\end{tabular}

\begin{tabular}{|r|c|c|c|c|c|c|}
\hline \multicolumn{7}{|c|}{ Case Processing Summary } \\
\hline & \multicolumn{7}{|c|}{ Cases } \\
\cline { 2 - 7 } & $\mathbf{2}$ Valid & \multicolumn{2}{c|}{ Missing } & \multicolumn{2}{|c|}{ Total } \\
\cline { 2 - 7 } & $\mathbf{N}$ & Percent & $\mathbf{N}$ & Percent & N & Percent \\
\hline Gender *Gaming & 300 & $100.0 \%$ & 0 & $0.0 \%$ & 300 & $100.0 \%$ \\
\hline Table 4. Chi-Square Test.: Gender Vs Gaming \\
\hline
\end{tabular}

\begin{tabular}{|c|c|c|c|c|c|}
\hline & \multicolumn{2}{|c|}{ Gaming } & \multirow{2}{*}{ Total } \\
\hline & & & No & Yes & \\
\hline \multirow{4}{*}{ Gender } & \multirow{2}{*}{ Female } & Count & 119 & 61 & 180 \\
\hline & & Expected Count & 99.6 & 80.4 & 180.0 \\
\hline & \multirow{2}{*}{ Male } & Count & 47 & 73 & 120 \\
\hline & & Expected Count & 66.4 & 53.6 & 120.0 \\
\hline \multirow{2}{*}{\multicolumn{2}{|c|}{ Total }} & Count & 166 & 134 & 300 \\
\hline & & Expected Count & 166.0 & 134.0 & 300.0 \\
\hline
\end{tabular}

\begin{tabular}{|c|c|c|c|c|c|}
\hline & Value & $\mathbf{d f}$ & $\begin{array}{c}\text { Asymp. Sig. } \\
\text { (2-Sided) }\end{array}$ & $\begin{array}{c}\text { Exact Sig. } \\
\text { (2-Sided) }\end{array}$ & $\begin{array}{c}\text { Exact Sig. } \\
\text { (1-Sided) }\end{array}$ \\
\hline $\begin{array}{c}\text { Pearson Chi- } \\
\text { Square }\end{array}$ & $21.150^{\mathrm{a}}$ & 1 & .000004 & & \\
\hline $\begin{array}{c}\text { Continuity } \\
\text { Correction }\end{array}$ & 20.073 & 1 & .000 & & \\
\hline Likelihood Ratio & 21.285 & 1 & .000 & & .000006 \\
\hline $\begin{array}{c}\text { Fisher's Exact } \\
\text { Test }\end{array}$ & & & & .00004 \\
\hline N of Valid Cases & 300 & & & & \\
\hline & $\begin{array}{l}\text { a cells (.0\%) have expected count less than 5. The minimum } \\
\text { expected count is 53.60. } \\
\text { b. Computed only for a 2 } 2 \text { 2 table }\end{array}$ \\
b. Table 4 (iii). Chi-Square Tests \\
\hline \multicolumn{7}{|c|}{}
\end{tabular}

\begin{tabular}{|c|c|c|c|c|c|c|}
\hline \multicolumn{7}{|c|}{ Case Processing Summary } \\
\hline & \multicolumn{7}{|c|}{ Cases } \\
\cline { 2 - 7 } & Valid & Mercent & N & Percent & N & Percent \\
\hline & 300 & $100.0 \%$ & 0 & $0.0 \%$ & 300 & $100.0 \%$ \\
\hline $\begin{array}{c}\text { Gender * Social- } \\
\text { Networking }\end{array}$ & \multicolumn{7}{|c|}{} \\
\hline Table 5. Chi-Square Test. Gender Vs Social-Networking \\
\hline
\end{tabular}

\begin{tabular}{|c|c|c|c|c|c|}
\hline & & & \multicolumn{2}{|c|}{ Social-Networking } & \multirow{2}{*}{ Total } \\
\hline & & & No & Yes & \\
\hline \multirow{4}{*}{ Gender } & \multirow{2}{*}{ Female } & Count & 41 & 139 & 180 \\
\hline & & Expected Count & 82.2 & 97.8 & $\mathbf{1 8 0 . 0}$ \\
\hline & \multirow{2}{*}{ Male } & Count & 96 & 24 & 120 \\
\hline & & Expected Count & 54.8 & 65.2 & 120.0 \\
\hline \multirow{2}{*}{\multicolumn{2}{|c|}{ Total }} & \begin{tabular}{|c|} 
Count \\
\end{tabular} & 137 & 163 & $\mathbf{3 0 0}$ \\
\hline & & \begin{tabular}{|l|} 
Expected Count \\
\end{tabular} & 137.0 & 163.0 & 300.0 \\
\hline \multicolumn{6}{|c|}{ Table 5(ii). Gender * Social-Networking Cross Tabulation } \\
\hline
\end{tabular}

\begin{tabular}{|c|c|c|c|c|c|}
\hline & Value & df & $\begin{array}{l}\text { Asymp. Sig. } \\
\text { (2-Sided) }\end{array}$ & $\begin{array}{l}\text { Exact Sig. } \\
\text { (2-Sided) }\end{array}$ & $\begin{array}{l}\text { Exact Sig. } \\
\text { (1-Sided) }\end{array}$ \\
\hline $\begin{array}{l}\text { Pearson Chi- } \\
\text { Square }\end{array}$ & $95.016^{\mathrm{a}}$ & 1 & $1.8886 \mathrm{E}-22$ & & \\
\hline $\begin{array}{l}\text { Continuity } \\
\text { Correction }\end{array}$ & 92.724 & 1 & .000 & & \\
\hline Likelihood Ratio & 100.368 & 1 & .000 & & \\
\hline \begin{tabular}{|c|} 
Fisher's Exact \\
Test \\
\end{tabular} & & & & $3.3561 \mathrm{E}-23$ & $2.4022 \mathrm{E}-23$ \\
\hline $\mathrm{N}$ of Valid Cases & 300 & & & & \\
\hline \multicolumn{6}{|c|}{$\begin{array}{ll}\text { a. } & 0 \text { cells }(.0 \%) \text { have expected count less than } 5 \text {. The minimum } \\
\text { expected count is } 54.80 . \\
\text { b. } \\
\text { Computed only for a } 2 \times 2 \text { table }\end{array}$} \\
\hline \multicolumn{6}{|c|}{ Table 5 (iii). Chi-Square Tests } \\
\hline
\end{tabular}

\begin{tabular}{|c|c|c|c|c|c|c|}
\hline \multicolumn{7}{|c|}{ Case Processing Summary } \\
\hline & \multicolumn{6}{|c|}{ Cases } \\
\cline { 2 - 6 } & \multicolumn{2}{|c|}{ Valid } & \multicolumn{2}{c|}{ Missing } & \multicolumn{2}{c|}{ Total } \\
\cline { 2 - 6 } & N & Percent & N & Percent & N & Percent \\
\hline Gender*Effects & 300 & $100.0 \%$ & 0 & $0.0 \%$ & 300 & $100.0 \%$ \\
\hline Table 6. Chi-Square Test: Gender Vs Effect \\
\hline
\end{tabular}




\begin{tabular}{|c|c|c|c|c|c|}
\hline & \multicolumn{2}{|c|}{ Effects } & \multirow{2}{*}{ Total } \\
\hline & & & No & Yes & \\
\hline \multirow{4}{*}{ Gender } & \multirow{2}{*}{ Female } & Count & 96 & 84 & 180 \\
\hline & & Expected Count & 69.6 & 110.4 & 180.0 \\
\hline & \multirow{2}{*}{ Male } & Count & 20 & 100 & 120 \\
\hline & & Expected Count & 46.4 & 73.6 & 120.0 \\
\hline \multirow{2}{*}{\multicolumn{2}{|c|}{ Total }} & Count & 116 & 184 & 300 \\
\hline & & Expected Count & 116.0 & 184.0 & 300.0 \\
\hline \multicolumn{6}{|c|}{ Table 6 (ii). Gender ${ }^{*}$ Effects Cross Tabulation } \\
\hline
\end{tabular}

\begin{tabular}{|c|c|c|c|c|c|}
\hline & Value & df & $\begin{array}{c}\text { Asymp. Sig. } \\
\text { (2-Sided) }\end{array}$ & $\begin{array}{c}\text { Exact Sig. } \\
\text { (2-Sided) }\end{array}$ & $\begin{array}{c}\text { Exact Sig. } \\
\text { (1-Sided) }\end{array}$ \\
\hline $\begin{array}{c}\text { Pearson Chi- } \\
\text { Square }\end{array}$ & $40.817 \mathrm{a}$ & 1 & $1.6716 \mathrm{E}-10$ & & \\
\hline $\begin{array}{c}\text { Continuity } \\
\text { Correction }\end{array}$ & 39.286 & 1 & .000 & & \\
\hline Likelihood Ratio & 43.473 & 1 & .000 & & \\
\hline $\begin{array}{c}\text { Fisher's Exact } \\
\text { Test }\end{array}$ & & & & $7.6486 \mathrm{E}-11$ & $5.3524 \mathrm{E}-11$ \\
\hline N of Valid Cases & 300 & & & & \\
\hline $\begin{array}{c}\text { a. } \\
\text { 0 cells (.0\%) have expected count less than 5. The minimum }\end{array}$ \\
b. Tabected count is 46.40. \\
Computed only for a 2 x 2 table \\
\hline \multicolumn{7}{|c|}{ Table (iii). Chi-Square Tests } \\
\hline
\end{tabular}

Chi-square test was done and the result are association between Gender Vs Usage of Pattern (Gaming, Social Networking) with $\chi 2 \mathrm{~g}(1, \mathrm{~N}=300)=21.150, \mathrm{p}=0.000004<=$ $0.05 ; \chi 2$ s-n $(1, \mathrm{~N}=300)=95.016, \mathrm{p}=1.8886 \mathrm{E}-22<=0.05$; and Gender Vs Effects with $\chi 2$ e $(1, N=300)=40.187, p=1.6716 \mathrm{E}-$ $10<=0.05$ was found to be statistically significant.

\section{DISCUSSION}

The present study was conducted in Govt. Medical College, Nizamabad, among under graduates. Majority belonged to $21-$ 22 years. There were more females $(60.3 \%)$ than males in the group. Majority belonged to upper middle and upper class of modified Kuppuswamy socioeconomic status.

Of the 300 students, majority (61.33\%) of them used Smart Phone for $>4$ hours per day. Most of them were using for social networking and gaming. Almost half of the males $(48.73 \%)$ check their phone every $10-15$ minutes. ${ }^{12}$ Class room usage of Smart Phone was found to be very high in both males and females. Almost one fourth of the students carry their Smart Phone to wash room and use it even after midnight. ${ }^{3}$ Chatting with strangers was felt comfortable by $18.6 \%$ of the students.

Social networking was predominantly playing a significant role behind student behaviours, like frequently checking the phone, using the phone in class rooms, getting annoyed when interrupted and feeling in secured when others use their phone.

Certain significant gender differences were found in the Smart Phone usage. ${ }^{3}$

Males were more significantly checking the phone frequently, preferring to use phone even at home, using while dining, carrying it to the wash room, using the phone beyond midnight and chatting with strangers, when compared to females.

Two-thirds (65\%) of the subjects were experiencing symptoms like headache after using smart phone for longer hours. One third (31.6\%) of the students feel that their grades have come down because of Smart Phone usage and 16.3\% of them felt that they gained weight after using Smart Phone. ${ }^{19}$ Almost half of the students felt that there was no other better alternative to the Smart Phone.

\section{CONCLUSIONS}

The pattern of use differs between males and females. Usage for social networking is more among females. Usage after midnight and chatting with strangers is more prevalent among males. Parental concern about over usage of smartphone is more among males. Males are more insecure when others use their smartphone when compared to females. Risky behaviours like chatting with strangers is noticeably prevalent among the students. Accompanying behaviours like getting annoyed/restlessness when interrupted, are a point of concern. Factors like using the smartphone till late in the night might cause less sleep which might lead to less concentration in the classrooms. Also, usage while in classroom is very high, this might also affect their concentration on studies. Symptoms like headache, eyestrain and stress were found in majority of the students after using the smartphone for a long time.20 All these factors might affect their concentration, academic performance and also their health in the long run. In the existing scenario the need of the hour is to educate and create awareness among the students about the ill effects of over usage of smart phone, not only on their health but also on their studies and healthy life style. Timely supervision and counseling need to be given to those who are using smart phones for an alarmingly increasing duration. Educational institutions need to involve the students in extra-curricular activities to a larger extent, to limit their sedentary habits and make their routine more interesting.

\section{REFERENCES}

[1] Sarwar M, Soomro TR. Impact of smartphone's on society. Eur J Sci Res 2013;98(2):216-26.

[2] Al-Khlaiwi T, Meo SA. Association of mobile phone radiation with fatigue, headache, dizziness, tension and sleep disturbance in Saudi population. Saudi Med J 2004;25(6):732-6.

[3] Jamal A, Sedie R, Haleem KA, et al. Patterns of use of 'smart phones' among female medical students and self-reported effects. J Taibah University Medical Sciences 2012;7(1):45-9.

[4] Jenaro C, Flores N, Gómez-Vela M, et al. Problematic internet and cell-phone use: Psychological, behavioural and health correlates. Addiction Research and Theory 2007;15(3):309-20.

[5] Beranuy M, Oberst U, Carbonell X, et al. Problematic Internet and mobile phone use and clinical symptoms in college students: the role of emotional intelligence. Computers in Human Behavior 2009;25(5):1182-7.

[6] Aggarwal M, Grover S, Basu D. Mobile phone use by resident doctors: tendency to addiction-like behaviour. German J Psychiatry 2012;15(2):50-5.

[7] Van den Bulck J. Television viewing, computer game playing, and internet use and self-reported time to bed and time out of bed in secondary-school children. Sleep 2004;27(1):101-4.

[8] Thomée S, Härenstam A, Hagberg M. Mobile phone use and stress, sleep disturbances and symptoms of depression among young adults - a prospective cohort study. BMC Public Health 2011;11:66. 
[9] Dixit S, Shukla H, Bhagwat A, et al. A study to evaluate mobile phone dependence among students of a medical college and associated hospital of central India. Indian J Community Med 2010;35(2):339-41.

[10] Gupta N, Garg S, Arora K. Pattern of mobile phone usage and its effects on psychological health, sleep and academic performance in students of a medical university. Nat J Physiology, Pharmacy and Pharmacology 2016;6(2):132-9.

[11] Prasad M, Patthi B, Singla A, et al. Nomophobia: a cross-sectional study to assess mobile phone usage among dental students. J Clin Diagn Res 2017;11(2):ZC34-ZC9.

[12] De la Puente MP, Balmori A. Addiction to cell phones: are there neurophysiological mechanisms involved? Proyecto 2007;61:8-12.

[13] Khan MM. Adverse effect of excessive mobile phone use. Int J Occup Med Environ Health 2008;21(4):28993.

[14] Basu S. A comment on "nomophobic behaviours among smartphone using medical and engineering students in two colleges of West Bengal" letter by Dasgupta et al. (2017). Indian J Public Health 2018;62(1):68-9.
[15] Buck M. Is a new non-drug addiction emerging? School and Health 2008;21:15-9.

[16] Hocking B, Westerman R. Neurological abnormalities associated with mobile phone use. Occup Med 2000;50(5):366-8.

[17] Hocking B. Preliminary report: symptoms associated with mobile phone use. Occup Med (Lond) 1998;48(6):357-60.

[18] Cinel C, Russo R, Boldini A, et al. Exposure to mobile phone electromagnetic fields and subjective symptoms: a double-blind study. Psychosom Med 2008;70(3):345-8.

[19] Van den Bulck J. Adolescent use of mobile phones for calling and for sending text messages after lights out: results from a prospective cohort study with a oneyear follow-up. Sleep 2007;30(9):1220-3.

[20] Oftedal G, Wilen J, Sandstromt M, et al. Symptoms experienced in connection with mobile phone use. Occup Med (Lond) 2000;50(4):237-45. 